\title{
Pengaruh Non-Performing Loan dan Loan to Deposit Ratio terhadap Cadangan Kerugian Penurunan Nilai
}

\section{Effect of non-performing loan and loan to deposit rasio to loan loss provision}

\section{Siti Alawiyah Vebriana}

D3 Keuangan dan Perbankan, Politeknik Negeri Bandung

E-mail: siti.alawiyah.kepn17@polban.ac.id

\section{Diharpi Herli Setyowati}

Jurusan Akuntansi, Politeknik Negeri Bandung

E-mail: diharpi.herli@polban.ac.id

\section{Ade Ali Nurdin}

Jurusan Akuntansi, Politeknik Negeri Bandung

E-mail: ade.nurdin@polban.ac.id

\begin{abstract}
The main activity of the bank is to collect and raise funds from third-party channels through credit. In practice, conventional banks are faced with bad debt problems. The Bank's effort to anticipate bad credit is by establishing reserve funds in the form of Loan Loss Provisions (CKPN). The effect of NPL and LDR on CKPN is important to study because it can Maintain good bank performance. The sample size in this study is 36 banks listed on IDX. The data analysis technique used in this study is panel data regression analysis technique followed by classical hypothesis testing. The results of this study show that NPL have a positive impact on CKPN. The regression test results show that $L D R$ has a negative impact on CKPN. The results of NPL and LDR using F test were positive and significant for CKPN.
\end{abstract}

Keywords: non-performing loan, loan to deposit ratio, loan loss provisions, conventional banks

\section{Pendahuluan}

Pengembangan sektor keuangan terutama dalam mengembangkan sektor perbankan di Indonesia diharapkan membawa perubahan positif bagi perekonomian nasional. Salah satu cara pengembangan sektor keuangan adalah untuk menyediakan Sektor Jasa Keuangan (SJK) yang ideal. SJK memiliki fungsi sebagai sarana intermediasi keuangan, menyediakan dana untuk produksi dan konsumsi publik, dan sebagai sarana menyimpan kekayaan yang ekonomis, efektif dan efisien bagi pengguna dari SJK pelayanan publik (Hoesada, 2018).

Bank sebagai sektor jasa keuangan menjadi Lembaga intermediasi menerima dan menyalurkan dana masyarakat dalam jumlah yang besar. Bank mempunyai peran penting dalam menyalurkan dana tersebut kepada masyarakat kembali dengan adanya bank masyarakat semakin mudah mendapatkan modal pinjaman yang diberikan dalam bentuk kredit. Kredit adalah salah satu bentuk dari Aktiva Produktif dan usaha bank dalam menyalurkan dana yang telah dikumpulkan dari masyarakat yaitu sebagai salah satu sumber utama pendapatan bank.

Proses penyaluran kredit memiliki risiko kerugian bagi bank yang dapat disebut juga sebagai risiko kredit. Risiko kredit ialah kerugian yang disebabkan oleh ketidakupayaan debitur untuk membayar kredit apabila jatuh tempo. Sebagai antisipasi, bank diwajibkan untuk membentuk dan 
mengatur cadangan dana. Dalam peraturan perbankan Indonesia yang mengacu pada PSAK 50 dan 55 untuk mengatasi risiko kehilangan kerugian kredit Bank dalam meminimalkan risiko yang terjadi kemudian membentuk Cadangan Penyisihan Penurunan Kerugian (CKPN).

CKPN adalah cadangan bank diciptakan dengan tujuan mengatasi risiko kehilangan dana dalam aktiva produktif. Bank wajib mengalokasikan persentase tertentu dari saldo pinjaman menjadi CKPN. dana kredit yang berkurang terjadi karena dana tersebut dibentuk CKPN (Rizkatriania, 2015). Menurut Fitriana (2015) Bank harus berhati-hati - hati dalam menentukan jumlah CKPN dari kesalahan saat bank menentukan jumlah CKPN bank juga bisa menderita kerugian karena aset yang harus produktif dan bisa menghasilkan keuntungan berubah menjadi aset non-produktif karena disimpan ke dalam CKPN. Bank konvensional di indonesia masih belum mampu membentuk CKPN sesuai dengan apa yang ditetapkan oleh Bank Indonesia yang setidaknya 1 persen. Oleh karena itu perlu dalam analisis yang lebih jelas tentang faktor-faktor yang menyebabkan CKPN tidak mencapai batas yang ditetapkan oleh Bank Indonesia.

Faktor yang mempengaruhi CKPN adalah Non-Performing Loan (NPL) dan Loan to Deposit Ratio(LDR). NPL juga disebut sebagai kemampuan gagal bayar. Besarnya CKPN hanya dibentuk jika terdapat bukti objektif bahwa debitur mengalami gagal bayar. oleh sebab itu besarnya NPL mempengaruhi jumlah CKPN yang harus dibentuk. LDR adalah rasio antara jumlah pinjaman untuk modal dan ekuitas. Dalam penelitian ini LDR digunakan untuk mengukur kebutuhan bank untuk dana eksternal. Dalam kepentingan investor bank harus mengurangi CKPN bahwa investor menganggap bahwa risiko yang dihadapi oleh bank-bank kecil.

\section{Tabel I.1 Data Rata-Rata NPL, LDR dan CKPN pada Bank Konvensional Periode 2014-2018}

\begin{tabular}{|c|c|c|c|c|c|}
\hline Tahun & 2014 & 2015 & 2016 & 2017 & 2018 \\
\hline NPL (\%) & 2.16 & 2.49 & 2.93 & 3.16 & 2.37 \\
\hline LDR (\%) & 89,7 & 89,42 & 92,11 & 90,04 & 92,19 \\
\hline $\begin{array}{c}\text { CKPN (Milliar } \\
\text { Rupiah) }\end{array}$ & 90.454 & 116.540 & 153.245 & 157.143 & 164.535 \\
\hline
\end{tabular}

Terlihat pada Tabel I.1 CKPN naik setiap tahun. NPL selalu naik dari tahun 2014 sampai 2017, kenaikan tersebut diakibatkan oleh dana yang disalurkan oleh bank tersebut mengalami masalah atau gagal bayar. Karena nasabah gagal membayar kewajibannya kepada bank. Meningkatnya kredit bermasalah berdampak pada naiknya CKPN dari tahun ke tahun pergerakan NPL yang searah dengan CKPN memperlihatkan indikasi positif. Tetapi, di tahun 2018 NPL turun sebanyak 0,79\% dengan CKPN yang tetap naik di tahun 2018 sebanyak 4,7\% hal ini bertolak belakang dengan pernyataan bahwa NPL berpengaruh signifikan positif terhadap CKPN yang didukung penelitian sebelumnya yang dilakukan oleh (Fitriana, 2015)

LDR mengalami kenaikan secara fluktuatif setiap tahunnya namun turunnya LDR di tahun 2017 dan naiknya CKPN di tahun yang sama. CKPN yang seharusnya bepengaruh negatif terhadap CKPN berdasarkan penelitian yang dilakukan (Napisah, 2020).

Pada ketika kondisi ekonomi membaik (booming) ditandai dengan membaiknya kinerja perekonomian, meningkatnya pendapatan masyarakat, dan membaiknya kemampuan bayar debitur, bank cenderung untuk menurunkan CKPN sehingga lebih banyak dana yang tersedia untuk distribusikan. Hal itu sejalan dengan menurunnya persentase provisi dibandingkan dengan total kredit. Pada pasar yang kompetitif bank akan melonggarkan aturan penyaluran kredit dan pinjaman suku bunga atau premi risiko rendah / kompetitif. Pada kondisi tersebut terbuka risiko kredit lalu 
ketika ekonomi memasuki fase kontraksi menunjukkan bahwa bank akan meningkatkan kredit yang diberikan dengan cara menurunkan CKPN saat kondisi ekonomi membaik.

Penjabaran latar belakang peneliti mengangkat "Pengaruh Non-Performing Loan (NPL) dan Loan to Deposit Rasio (LDR) Terhadap Cadangan Kerugian Penurunan Nilai (CKPN)" sebagai judul tugas akhir ini meneliti pengaruh dari NPL dan LDR terhadap CKPN Studi Kasus pada Bank Konvensional yang Tercatat di Bursa Efek Indonesia 2014-2018.

\section{Kajian Pustaka}

\subsection{Risiko Kredit}

Risiko kredit merupakan risiko akibat kredit yang tidak dibayarkan. Bank harus berhati-hati dalam aliran dana karena kredit merupakan salah satu dari penghasilan besar bagi bank. Kegagalan bayar dalam kredit menyebabkan bank mengalami kerugiaan. Kewaspadaan ini mungkin termasuk penyediaan kebutuhan yang jelas untuk masing-masing debitur.

\subsection{CKPN}

CKPN adalah cadangan bank diciptakan dengan tujuan mengatasi risiko kehilangan dana dalam aktiva produktif. Bank wajib mengalokasikan persentase tertentu dari saldo pinjaman menjadi CKPN. Perhitungan rasio CKPN dirumuskan sebagai berikut :

$$
\text { CKPN (Kredit) }=\frac{\text { CKPN yang dibentuk }}{\text { kredit yang disalurkan }} \times 100 \%
$$

\subsection{NPL}

NPL juga disebut sebagai gagal bayar atau kredit yang tidak menghasilkan. Bank harus menanggung kerugian dalam kegiatan dan memberikan kontribusi untuk peningkatan cadangan dana bank. Semakin besar NPL, akan menyebabkan CKPN yang lebih tinggi yang juga berarti mengharuskan bank menyisihkan kerugian yang semakin besar. Jadi dapat dirumuskan hipotesis bahwa pengaruh positif pada CKPN.

\subsection{LDR}

$$
\mathrm{N} P L=\frac{\text { Total Kredit Bermasalah }}{\text { Total Outstanding Kredit }} \times 100 \%
$$

LDR adalah rasio yang mengukur kemampuan bank untuk memenuhi kewajiban keuangan yang harus dipenuhi atau sering disebut rasio likuiditas. Rumusan LDR yang dipakai sebagai berikut :

$$
\mathrm{LDR}=\frac{\text { Total Kredit yang diberikan }}{\text { Total Dana Pihak Ketiga }} \times 100 \%
$$

\section{Metode Penelitian}

\subsection{Jenis dan Sumber Data}

Penggunaan data sekunder yang didapatkan pada laporan keuangan tahun 2014-2018 bank konvensional yang terdaftar di BEI. Bersumber dari website resmi bursa efek Indonesia www.idx.com.

\subsection{Populasi Penelitian}

Populasi dalam penelitian ini adalah perusahaan perbankan yang merupakan 43 Bank Konvensional yang yang menerbitkan laporan keuangan tahunan di Bursa Efek Indonesia dalam kurun waktu penelitian 2014- 2018. 


\subsection{Sampel Penelitian} sampel :

Kriteria penentuan sampel menggunakan teknik purposive sampling. Kriteria tertentu pemilihan

1. Bank Kovensional yang terdaftar pada Bursa Efek Indonesia(BEI) sampai tahun 2018.

2. Tersedianya variabel NPL, LDR dan CKPN pada laporan-keuangan tahun 2014-2018

Berdasarkan kriteria tersebut, maka sampel yang digunakan dalam penelitian ini sejumlah 36 Bank Konvensional.

\subsection{Teknik Analisis Data}

\subsubsection{Analisis Deskriptif}

Memiliki fungsi sebagai deskripsi variabel yang diteliti melalui sampel didasarkan pada nilai minimum, nilai maksimum, mean, dan standar deviasi.

\subsubsection{Uji Spesifikasi Model dengan Uji Chow}

Uji chow digunakan untuk memilih spesifikasi model Fixed Effect atau Common Effect yang sebaiknya dipakai dalam penelitian. Dengan hipotesis :

$$
\begin{aligned}
& H_{0}: \quad \text { Common Effect } \\
& H_{1}: \quad \text { Fixed Effect }
\end{aligned}
$$

Jika hasil spesifikasi menunjukkan Chi-square lebih dari 0.05, maka model yang dipilih adalah Common Effect. Sebaliknya, apabila Chi-Square adalah kurang daripada 0.05 maka model yang perlu digunakanaadalah Fixed Effect.

\subsubsection{Uji Spesifikasi Model dengan Uji Hausman}

Uji ini untuk menentukan model yang harus digunakan, yaitu Fixed Effect Model(FEM) atau RandomaEffect Model(REM). Hipotesis dalam uji Hausman sebagai berikut :

\section{Ho: Random Effect Model}

\section{Ha : Fixed Effect Model}

\subsubsection{Uji Asumsi Klasik}

Uji normalitas bertujuan untuk menguji model regresi digunakan untuk menilai distribusi variabel yang digunakan dalam penelitian. Data terdistribusi secara normal atau tidak. Pengambilan keputusan dengan Jargue-Bera test atau J-B test yaitu apabila probabilitas $>5 \%$, maka variabelvariabel tersebut berdistribusi normal.

Uji Multikolinieritas tes bertujuan untuk menguji apakah model regresi ditemukan korelasi antara variabel independen. Dapat dilakukan beberapa cara untuk melihat apakah ada multikolinearitas dalam model regresi. Menurut Gujarati (2013), jika koefisien korelasi antar variabel bebas lebih dari 0,8 maka dapat disimpulkan bahwa model mengalami masalah multikolinearitas. Sebaliknya, koefisien korelasi kurang dari 0,8 maka model bebas dari multikolinearitas.

Uji heteroskedastisitas bertujuan untuk menguji apakah ada ketimpangan dalam model regresi varians dari residual dari pengamatan ke pengamatan lain (Ghozali, 2006).

Uji autokorelasi adalah analisis statis untuk menentukan ada korelasi variabel dalam 
prediksi model dengan perubahan waktu. Jika ada korelasi maka ada masalah yang disebut autokorelasi (Ghozali, 2005) menggunakan nilai Durbin-Watson (DW test) untuk menilai autokorelasi.

\subsubsection{Uji Hipotesis}

Koefisien determinasi Adjusted $\mathrm{R}$ Square $\left(\mathrm{R}^{2}\right)$ digunakan untuk mengukur persentase dari totalavariasi dalam variabel dependen dijelaskan oleh semua variabel independen. Dengan kata lain,nilai $\left(\mathrm{R}^{2}\right)$ menunjukkan bagaimana model regresi mampu menjelaskan variabel dependen.

Uji T digunakan untuk menguji pengaruh variabel secara parsial independen terhadap variabel dependen, yaitu pengaruh masing - masing terdiri dari variabel independen

Uji F-hitung dirancang untuk menguji pengaruh model regresi secara simultan semua variabel independen terhadap variabel dependen. Pengujiannya adalah dengan menentukan kesimpulan dengan taraf signifikansi sebesar 0,05 .

\section{Hasil dan Pembahasan}

\subsection{Hasil Penelitian}

\subsubsection{Analisis Deskriptif}

Dilakukan analisis deskriptif, maka hasil statistik yang diperoleh dari data variabel - variabel yang digunakan dalam penelitian ini adalah sebagai berikut:

Tabel IV.2 Data Statistik Deskriptif

\begin{tabular}{|l|r|r|r|r|r|r|}
\hline & $\begin{array}{c}\text { Jumlah } \\
\text { Sampel }\end{array}$ & \multicolumn{1}{c|}{ Min } & \multicolumn{1}{c|}{ Max } & Mean & \multicolumn{1}{c|}{$\begin{array}{c}\text { Std } \\
\text { Deviasi }\end{array}$} & \multicolumn{1}{c|}{ Varians } \\
\hline NPL & 180 & .16 & 15.82 & 3.0557 & 2.32750 & 5.417 \\
\hline LDR & 180 & 41.99 & 145.26 & 84.8481 & 13.54479 & 183.461 \\
\hline CKPN & 180 & 16.05 & 35603 & 20.902 & 501.240. & 25.124 .179$. \\
& 123.00 & 711.225 & 254.824 & 305.638 .900 \\
\hline
\end{tabular}

Berdasarkan tabel IV.2 dapat dijelaskan penelitian ini memiliki jumlah data sampel sebanyak 180 variabel dengan nilai minimum NPL senilai 0,16 dan nilai maksimum 15,82 . terlihat nilai NPL berada antara 0,16 sampai 15,82 dengan rata-rata NPL 3,0557 dan standar deviasi 2,32750 penyebaran data yang lebih kecil karena nilainya lebih rendah dari rata-rata.

Pada tabel IV.2 Nilai LDR sebesar 41.99 dan nilai maksimum 145,26. terlihat nilai LDR nilai 41,99 sampai 145,26 rata-rata LDR 85,0957 dan standar deviasi 13,454479 penyebaran data yang lebih kecil karena nilainya lebih rendah dari rata-rata.

Nilai minimum CKPN sebesar 16,05 dan nilai maksimum 35603123. terlihat nilai CKPN nilai 5,27 sampai 35603123 rata-rata CKPN 2033922,466 dan standar deviasi sebesar 4955439,91.

\subsubsection{Uji Asumsi Klasik}

Uji Normalitas digunakan untuk mengetahui distribusi variabel berdistribusi normal atau tidak. Pengujian normalitas menggunakan Teknik analisis Kolmogorov-Smirnov. 
Tabel IV.3 Hasil Uji Normalitas

\begin{tabular}{|l|l|l|l|}
\hline \multirow{2}{*}{} & \multicolumn{3}{|l|}{ Kolmogorov-Smimov ${ }^{2}$} \\
\cline { 2 - 4 } & Statistic & Df & Sig. \\
\hline Unstandardized Residual & .050 & 180 & $0.089^{*}$ \\
\hline
\end{tabular}

Pada Tabel IV.3 terlihat data sampel 180 dengan nilai signifikansi 0,089. Nilai signifikansi lebih dari 0,05 sehingga didapat data dengan distribusi normal.

Uji Multikolinearistas. Pada tabel IV.4 berikut Hasil Uji Multikolinearitas: Tabel IV.4 Hasil Uji Multikolinearitas

\begin{tabular}{|l|l|l|}
\hline Variabel & NPL & LDR \\
\hline NPL & 1.000000 & 0.156573 \\
\hline LDR & 0.156573 & 1.000000 \\
\hline
\end{tabular}

Terlihat tabel IV.4 merupakan korelasi antar variabel, dapat dilihat bahwa nilai korelasi tidak ada yang melebihi 0,9 sehingga tidak terjadi multikolinearitas.

Uji Autokorelasi. Untuk mendeteksi masalah, autokorelasi bisa menjadi tes digunakan Durbin-Watson (DW).

Tabel IV.5 Hasil Uji Autokolerasi

\begin{tabular}{|l|r|l|r|}
\hline \multicolumn{4}{|c|}{ Effects Specification } \\
\hline \multicolumn{4}{|c|}{ Cross-section fixed (dummy variables) } \\
\hline Root MSE & 0.374418 & R-squared & 0.905460 \\
\hline Mean dependent var & 5.143 .222 & Adjusted R-squared & 0.880826 \\
\hline S.D. dependent var & 1.221 .118 & S.E. of regression & 0.421549 \\
\hline Akaike info criterion & 1.295 .333 & Sum squared resid & 2.523 .396 \\
\hline Schwarz criterion & 1.969 .402 & Log likelihood & 7.857 .998 \\
\hline Hannan-Quinn criter. & 1.568 .639 & F-statistic & 3.675 .685 \\
\hline Durbin-Watson stat & 2.017 .315 & Prob(F-statistic) & 0.000000 \\
\hline
\end{tabular}

Tabel IV.5 diketahui bahwa nilai DW $>$ DU, dan DW $<(\mathrm{DU}-4)(\mathrm{DU}=1.7786 ; \mathrm{DL}=$ $1.7337, \mathrm{n}=180, \mathrm{k}=2 ; \mathrm{a}=0.05)$. Sehingga tidak terjadi autokorelasi pada model estimasi yang dipakai. data dapat dipakai untuk uji hipotesis

Uji heterokesdasitas dilakukan dengan melihat Prob F dari estimasi regeresi NPL dan LDR terhadap nilai residual absolut. Diketiahui nilai Prob. $<0,05$. Sehingga ada heterokesdasitas. Namun sebelumnya dilakukan uji Lagrange Multiplier untuk menentukan apakah digunakan dalam perbandingan Common Effect berikut hasilnya.:

Tabel IV.6 Hasil Uji Heteroskedastisitas

\begin{tabular}{|l|l|l|l|}
\hline & \multicolumn{3}{l|}{ Test Hypothesis } \\
\hline & Cross-section & Time & Both \\
\hline \multirow{2}{*}{ Breusch-Pagan } & 232.5529 & 0.516636 & 233.0695 \\
\cline { 2 - 4 } & $(0.0000)$ & $(0.4723)$ & $(0.0000)$ \\
\hline
\end{tabular}

Pada tabel IV.6 dapat dilihat pada nilai Beuch-Pagan, nilai p dari Cross Section $<0.05$ sehingga metode Random Effect akan tetap dipakai dibandingkan dengan Common Effect. Data dapat dipakai untuk uji selanjutnya. 


\subsubsection{Uji Chow}

Hasil dari estimasi Uji Chow menggunakan Eviews11:

Tabel IV.7 Hasil Uji Chow

\begin{tabular}{|ll|l|l|l|}
\hline Effects Test & Statistic & d.f. & Prob. \\
\hline Cross-section F & 33.737 .606 & $-35,142$ & 0.0000 \\
\hline $\begin{array}{l}\text { Cross-section } \\
\text { square }\end{array}$ & Chi- & 401.704 .411 & 35 & 0.0000 \\
\hline
\end{tabular}

Pada Tabel IV.7 dilihat nilai probabilitas cross-section adalah 0,0000 kurang dari 0,05 sehingga H1 terpenuhi dipilih metode estimasi Fixed Effect.

\subsubsection{Uji Hausman}

Hasil dari estimasi menggunakan efek spesifikasi random adalah sebagai berikut:

\section{Tabel IV.8 Hasil Uji Hausman}

\begin{tabular}{|l|l|l|l|}
\hline \multicolumn{4}{|l|}{ Test cross-section random effects } \\
\hline Test Summary & $\begin{array}{l}\text { Chi-Sq. } \\
\text { Statistic }\end{array}$ & $\begin{array}{l}\text { Chi-Sq. } \\
\text { d.f. }\end{array}$ & Prob. \\
\hline Cross-section random & 9.056 .457 & 2 & 0.0108 \\
\hline
\end{tabular}

Pada Tabel IV.8 dilihat nilai probabilitas cross-section sebesar 0,0108 yang dimana ini $<0,05$ sehingga $\mathrm{Ha}$ terpenuhi dimana dipilih metode estimasi Fixed Effect.

\subsubsection{Analisis Data Panel}

Hasil estimasi model regresi data panel adalah sebagai berikut: Tabel IV.9 Hasil Estimasi Model

\begin{tabular}{|l|l|l|l|l|}
\hline Variable & Coefficient & Std. Error & t-Statistic & Prob. \\
\hline C & 5.187899 & 1.501 .965 & 3.454 .073 & 0.0007 \\
\hline LDR & -0.145758 & 0.772997 & -0.188562 & 0.8507 \\
\hline NPL & 0.630470 & 0.138169 & 4.563 .029 & 0.0000 \\
\hline
\end{tabular}

Dari tabel IV.9 terlihat probabilitas NPL $0,000<0,05$. NPL berpengaruh signifikan terhadap CKPN. Sedangkan LDR memiliki nilai probabilitas 0,8507 lebih dari 0,05 yang berarti variabel ini tidak signifikan.

Hasil metode pengolahan data panel fixed effect diperoleh persamaan regresi sebagai berikut:

$$
\log 10(\mathrm{CKPN}) \text { it }=5.187-0.145 \log 10(\mathrm{LDR}) \text { it }+0.630 \log 10(\mathrm{NPL}) \text { it }+ \text { e it }+ \text { U I }
$$

Keterangan :

$\mathrm{i}=1,2, \ldots ., \mathrm{N}$ dan $\mathrm{t}=1,2, \ldots ., \mathrm{T}$.

$\mathrm{N}=$ jumlah sampel dan $\mathrm{T}=$ jumlah periode waktunya.

Dapat dilihat LDR berpengaruh negatif terhadap CKPN sedangkan NPL berpengaruh positif terhadap CKPN dengan catatan terdapat variabel pengganggu yang saling berhubungan antar bank dan antar waktu. 


\subsubsection{Koefisien Determinasi}

Koefisienadeterminasiamengukurapersentaseavariabelaindependenaterhadapavariabel dependen. Hasil dari perhitungan koefisien determinasi adalah sebagai berikut :

Tabel IV.10 Hasil Uji Koefisien Determinasi

\begin{tabular}{|l|r|l|r|}
\hline \multicolumn{4}{|c|}{ Weighted Statistics } \\
\hline Root MSE & 0.426273 & R-squared & 0.103023 \\
\hline Mean dependent var & 0.902301 & Adjusted R-squared & 0.092888 \\
\hline S.D. dependent var & 0.451343 & S.E. of regression & 0.429870 \\
\hline Sum squared resid & 3.270 .756 & F-statistic & 1.016 .475 \\
\hline Durbin-Watson stat & 1.558 .822 & Prob(F-statistic) & 0.000066 \\
\hline
\end{tabular}

Tabel VI.10, nilai adjusted R-squared 0.09288 atau 9.3\% CKPN berpengaruh oleh NPL dan LDR sedangkan $90.7 \%$ dijelaskan oleh variabel lain. contohnya ROA, CAR dan SIZE.

\subsubsection{Uji T}

Setelah dilakukannva uji $\mathrm{t}$ penjelasan hasil untuk masing-masing variabel bebas adalah sebagai berikut:

Tabel IV.11 Hasil Uji t

\begin{tabular}{|c|c|c|}
\hline Variable & t-Statistic & Prob. \\
\hline LDR & -0.188562 & 0.8507 \\
\hline NPL & 4.563 .029 & 0.0000 \\
\hline
\end{tabular}

Hasil statistik uji t untuk terlihat pada Tabel IV.11 variabel NPL diperoleh nilai untuk variabel NPL, nilai t-statistic $>$ ttabel $(\mathrm{df}=0.025 / 173, \mathrm{a}=0.05)$ dan nilai $\mathrm{p}<0.05$ sehingga berpengaruh signifikan secara parsial terhadap CKPN. LDR diperoleh diketahui bahwa nilai $\mathrm{t}-$ statistic dari LDR $<$ ttabel $(\mathrm{df}=0.025 / 173, \mathrm{a}=0.05) \mathrm{t}$-tabel adalah 1.97273 dan nilai $\mathrm{p}>0.05$ sehingga variabel LDR tidak berpengaruh signifikan secara parsial terhadap CKPN.

\subsubsection{Uji F}

\section{Hasil pengujian goodness of fit model menggunakan uji $\mathrm{F}$ dapat dilihat dalam tabel berikut}

\begin{tabular}{|l|c|}
\multicolumn{2}{c}{ Tabel IV.12 Hasil Uji F } \\
\hline F-statistic & 10.16475 \\
\hline Prob(F-statistic) & 0.000066 \\
\hline
\end{tabular}

Tabel IV.12 Nilai Sig $<0.05$ dan nilai Fhitung $>$ Ftabel menandakan bahwa NPL dan LDR berpengaruh secara simultan terhadap nilai CKPN.

\subsection{Pembahasan}

Pengaruh NPL terhadap CKPN. Adanya pengaruh positif antara NPL dan CKPN. Berdasarkan hasil tes parsial mempengaruhi nilai NPL CKPN diperoleh 4563 sedangkan Tabel $\mathrm{t}$ sebesar 1.972 dan sejumlah besar $0,000<0,05$. Karena thitung $>\mathrm{t}$ tabel dan nilai signifikan kurang dari 0,05 memiliki arti H1 diterima yang berarti NPL berpengaruh signifikan dan positif terhadap CKPN. Dana kredit diharapkan pendapatan bagi bank untuk membawa masalah serius untuk kinerja bank saat menjadi NPL dana akan disalurkan ke CKPN. Sesuai dengan penelitian yang dilakukan (Maretha Eka, 2015) meneliti bagaimana pengaruh NPL, CAR, ROA, LDR DAN SIZE terhadap CKPN pada Bank Konvensional yang terdaftar di BEI periode 2010-2014. Hasil 
penelitian menunjukkan bahwa variabel NPL berpengaruh signifikan positif terhadap CKPN. Hasil pada penelitian ini menunjukan bahwa NPL berpengaruh signifikan positif terhadap CKPN.

Pengaruh LDR terhadap CKPN. Hasil uji variabel LDR diperoleh nilai t-hitung sebesar 0,18856 dengan t-tabel sebesar 1,972 dan nilai probabilitas sebesar 0,8507 >0,05. Karena t hitung $<\mathrm{t}$ tabel dan nilai signifikan lebih besar dari 0,05 dapat disimpulkan $\mathrm{H} 2$ ditolak yang artinya LDR berpengaruh tidak signifikan dan negatif terhadap CKPN. menunjukkan penelitian ini bahwa LDR berpengaruh negatif terhadap CKPN. LDR yang menunjukkan bahwa risiko ketidakmampuan bank untuk memenuhi kewajibannya kepada pihak ketiga yang tidak mempengaruhi pembentukan CKPN Bank. Hasil penelitian ini juga konsisten dengan Hasil penelitian ini juga konsisten dengan Napisah (2020) dan Maulidiyah (2015) yang menyatakan bahwa likuiditas suatu bank tidak mempengaruhi besaran CKPN yang akan dibentuk.

Pengaruh NPL dan LDR terhadap CKPN. Berdasarkan perhitungan, secara simultan variable NPL dan LDR berpengaruh signifikan positif terhadap CKPN. Besarnya pengaruh 9,3\% atau variasi dari variabel independen yang digunakan dalam model, NPL dan LDR mampu menjelaskan hanya 9,3\% persen dari variabel variasi CKPN. Hasil juga menerima hipotesis ketiga yang ada pengaruh yang signifikan dan positif antara variable NPL dan LDR terhadap CKPN. Hasil penelitian ini didukung dengan penelitian yang oleh Maretha Eka Fitriani (2015) bagaimana pengaruh NPL, CAR, ROA, LDR DAN SIZE terhadap CKPN pada Bank Konvensional yang terdaftar di BEI periode 2010-2014. Hasil penelitian menunjukkan bahwa variabel NPL dan LDR berpengaruh positif terhadap CKPN.

\section{Penutup}

\subsection{Kesimpulan}

Hasil dari penelitian ini dan pengujian hipotesis pada bab sebelumnya, kesimpulan yang diambil adalah:

1. Hasil uji regresi ditemukan Non-Performing Loan(NPL) memiliki pengaruh positif dan signifikan pada Cadangan Kerugian Penurunan Nilai(CKPN). Perusahaan yang memiliki tingkat kolektibiltas kredit yang buruk cenderung memiliki cadangan dana yang banyak. Keuntungan dari kredit berubah menjadi kehilangan pendapatan bagi bank. Ini berarti bahwa bank-bank konvensional harus mempertimbangkan tingkat kredit, yang akan berdampak pada terjadinya kredit bermasalah untuk mencapai tingkat kepatuhan CKPN dengan ketentuan BI.

2. Hasil pengujian regresi diperoleh bahwa Loan to Deposit Ratio(LDR) memiliki pengaruh negatif dan tidak signifikan terhadap Cadangan Kerugian Penurunan Nilai(CKPN).

3. Pengujian secara bersama-sama variabel NPL dan LDR secara simultan mendapatkan hubungan positif dan signifikan terhadap CKPN. Nilai $R^{2}$ sebesar 9,3\% memperlihatkan variabel independen NPL dan LDR selama periode penelitian sedangkan sisanya dipengaruhi oleh variabel lain contohnya ROA, CAR dan SIZE.

\subsection{Saran}

Penelitian selanjutnya dapat mengikut sertakan semua jenis bank dan variabel lainnya dalam periode jangka waktu yang lebih lama pada penelitiannya sehingga penelitian lebih bervariasi data dengan lebih baik.

Kontribusi bagi bank untuk dipertimbangkan dalam keputusan untuk menetapkan jumlah CKPN di masa depan. NPL terbukti menjadi dampak positif dan signifikan terhadap bank dapat meningkatkankan CKPN ketika kredit macet meningkat. manajemen bank harus mempertimbangkan potensi yang akan menghasilkan peningkatan cadangan kerugian, pengurangan aset produktif bank yang dibentuk pada dana cadangan. 


\section{Daftar Pustaka}

Ghozali, I. (2006). Ghozali, Imam. 2006. Aplikasi Analisis Multivariate dengan Program SPSS. Semarang: Badan Penerbit UNDIP. In Analisis Multivariate dengan Program SPSS.

Gujarati, J. (2013). An "inverse" relationship between mathematics identities and classroom practices among early career elementary teachers: The impact of accountability. Journal of Mathematical Behavior. https://doi.org/10.1016/j.jmathb.2013.08.002

Hoesada, D. J. (2018). ABPN Pembangunan Sektor Keuangan NKRI. Komite Standar Akuntansi Pemerintahan. https://www.ksap.org/sap/apbn-pembangunan-sektor-keuangan-nkri/

Maretha Eka, F. (2015). Analisis Pengaruh NPL, CAR, ROA, LDR dan Size Terhadap CKPN (Studi Kasus pada Bank Konvensional yang Tercatat di Bursa Efek Indonesia 2010-2014). Skripsi.

Maulidiyah. (2015). Pengaruh Npl, Car, Dan Ldr Terhadap Cadangan Kerugian Penurunan Nilai (Ckpn) Pada Bank Konvensional Yang Tercatat Di Bursa Efek Indonesia Periode 2011-2015 Artikel. Artikel Ilmiah, 1-15.

Napisah. (2020). Pengaruh Non Performing Loan, Capital Adequacy Ratio Dan Loan To Deposit Ratio Terhadap Cadangan Kerugian Penurunan Nilai Dengan Kompetensi Komite Audit Sebagai Pemoderasi (Studi Empiris Pada Perusahaan Perbankan Yang Terdaftar Tahun 20142018 Di Bursa EF. Jurnal Riset Akuntansi, 15, 440-445.

Rizkatriania, A. (2015). No Title. engaruh Cadangan Kerugian Penurunan Nilai (CKPN) terhadap Net Interest Margin (NIM). 